\title{
Intensifiers, Reflexive and Reciprocal Pronouns in Argobba Language, Ethio-Semitic
}

\author{
Ousman Shafi Awol \\ Correspondence: Ousman Shafi Awol, Dean, College of Social Sciences and Humanities, Assistant Professor in \\ Linguistics, Ethiopia.
}

Received: November 26, 2019

Accepted: January 2, 2020

Online Published: February 12, 2020

doi:10.5430/elr.v9n1p25

URL: https://doi.org/10.5430/elr.v9n1p25

\begin{abstract}
Argobba is a South Ethio-Semitic language which is predominantly used in day-to-day communication by a population of about 140, 134 people in the Argobba Zone (Central Statistical Agency (2008:59), Ethiopia, whose linguistic features were not well described. The Argobba lives in the escarpment slopes of northeastern Shewa and southeastern Wollo, a minority of them are live in the adjoining settlements of the town of Harar in eastern Ethiopia.The Argobba make their living by cultivating plants, by breeding animals, weaving and by trade (Hussein, 2006:416). Most of the Argobba people are followers of Islam. As a result, the Islamic religion greatly influences the culture as well as the living style of the society. The central aim of this paper is to provide a comprehensive description and features of Intensifiers, reflexive and reciprocal pronouns of the Argobba language. The paper is descriptive in natureonly in Argobba language not comparing with other languages, since the study is mainly concerned with describing what is actually being in, and mainly relies on primary linguistic data. The linguistic data, i.e. the elicited grammatical data concerning Intensifiers, reflexive and reciprocal pronouns, was collected from native speakers of the language during 6 months of fieldwork conducted between 2015 and 2016 in five Kebeles and the administrative center of the Argobba. Intensifiers in Argobbaare derived from the noun 'self', which has the meaning 'self' as intensifier, or its reduplicated form 'self with self'. Reflexive pronouns are formed by combining 'self' with the possessive suffixes while reciprocal pronouns can be formed through a construction consisting of the comitative morpheme, which intersects between the reduplicated noun 'self', and the plural possessive suffixes.
\end{abstract}

Keywords: intensifiers, reflexive, reciprocal, comitative, morpheme, suffixes, possesive

\section{Introduction}

\section{The Argobba People}

The word "Argobba" denotes the language, the people and the place where Argobbas live. (Aklilu, 2000:174; Tesfaye, 2000:196-197, Stitz, 1973:188), thus, its intended meaning can be identified contextually.Based on the 2008 Census conducted by the Central Statistical Agency of Ethiopia (CSA) Argobba has a total population of 140, 134, which comprises $0.19 \%$ of the total population of the country, Ethiopia. Regarding the Argobbas, they are Muslim people who live in the North-Eastern mountainous part of Ethiopia, Amhara regional state, in South Wollo, Argobba Special Woreda and in Oromiya zone; in North and Eastern Shewa; in Affar region, at Gachinne and its vicinity; in Oromiya region, East and West Hararge Zones, and in the city of Harar and the surrounding villages. According to Hussein (2006:416), "Argobbas are distinguished by being either northern or southern Argobba. The southern Argobbas live around the road that goes from Addis Ababa to Harar, while northern live between and around the two roads that travel north from Addis Ababa on either side of the Rift Valley as far as the town Kemise". Most Argobbas are agriculturalists who grow sorgum, millet, maize, pulse, wheat and barley in addition to coffee, chat, tobacco and cotton as cash crops. Weaving and trade is also their profession. The stone buildings in Shonke resemble Harar. The buildings are rectangular in shape with flat roofs, approximately 3 to 3.5 meters high in length (Stitz, 1973:189). Scholars differ as to where the Argobba people have come from. Some say they were simply rural Harari whose ways of life have changed over time from the city dwellers. Others say the Argobbas are more recent arrivals.

Tesfaye (2000:197) gives three versions on the origin of Argobba. His first and second versions link the origin of Argobba to Arabia: either BeniUmayya [meaning "the son of Umeyya"] migrated from Arabia, some 800 years ago and settled in Northern Ethiopia, or they are descendants of the first Muslim asylum seekers in Ethiopia during the time of Prophet Mohammed. The third version holds that the Argobbas are not immigrants, and they are "indigenous 
people who accept Islam very early from religious leaders who came from Arabia" (Tesfaye, 2000:197). Weekes (1984:49-53) also has given three hypotheses on the origin of Argobba people. The first is based on oral tradition that BeniUmayya migrated from Arabiya and settled in Northern Ethiopia. The second hypothesis explains the expansion of the fortunate Wolasma dynasty to the south and conquered Muslim states of Shewa and established Sultanate of Ifat in 1285. After Ifat was defeated by Christian Kings (Dawit I \& Yishaq) in 1415, Wolasmas were retreated to the east and established the Adal [etymologically Arabic, meaning "justice maker" or "impartial ruler"] Sultanate with the capital near Harar. The last hypothesis explicates the link between the Northern and Southern Argobba communities with the two major historical events of the country: the war of Imam Ahmed Ibrahim al-Ghazi (Ahmed Gragn) of Adal in 1529 and his defeat in 1549; and the Oromo expansion right after the end of the war (Weekes, 1984:51). His second and last hypotheses raised similar idea that Argobbas are indigenous people.

Aklilu (2000) argues the first version and writes that Argobba's origin is related to the expansion of Aksumite Empire to the south past Angot. According to him, during that time, there were a nomadic people called "Gebal" in the Awash valley of south-eastern Shewa. Aklilu (2000:175) also described that this tribe, i.e., "Gebal", was the first to embrace Islam, and later on they came to be called Argobba. But, according to Ahmed (1999 E.C: 13), the first Islamic territory that Argobbas built was called "Jəbərty". "Jəbərty" is derived from "Abyssinian (Geez) word "gəbər" and it means "servants of God" for they were righteous/religious people who interact easily and live in harmony with other communities. Further research is needed to verify whether "Gebal" and "Jəbərty" refer the same tribe or denote different references. Ahmed (1999 E.C:9-11, 40) based on his fieldwork and interview with the elders of the community in Oromiya zone, south Wollo, maintained that the origin of Argobba is Arabia. Moreover, Ahmed (1999:175) also states that the Makhzumite dynasty who established an Islamic sultanate of Shawa was "a Meccan clan". Idris (1999:11) refers the time of their arrival to the south eastern Ethiopia from Arabia to the 8th century.

By now, the Argobba people have two autonomous Special Woredas (districts), one in Amhara National Regional State and the other in Affar National Regional State. The Special Woreda in South Wollo zone of the Amhara regional state, which is part of the study area, is established in 1998 at a center called Medina. Medina is $50 \mathrm{~km}$ far to the east of Kemise which is $375 \mathrm{~km}$ away from Addis Ababa to the way to Dessie.

\section{The Argobba Language}

Regarding the classification of Argobba languages there are similar classification among different scholars. According to Bender \& Hetzron, 1976:29; Hetzron, 1972, Argobba is the language that belongs to the south Ethio-Semitic sub-branch of the Afro-Asiatic language phylum. South Ethio-Semitic sub-branch is in turn classified into transversal south Ethiopic and outer south Ethiopic. The former is further divided into central and east Gurage. Argobba is categorized in central-transversal-south Ethiopic subgroup with Amharic. According to Meyer 2011:1222, Argobba is Amharic or Argobba language group belonging to the transversal south-Ethio Semitic division of the Ethio-Semitic language group. He further, divides the transversal south-Ethio-Semitic languages into two major typological groups, Amharic or Argobba group versus Eastern Gurage or Harari Group. Amharic or Argobba Group contains Amharic and Argobba languages and Eastern Gurage or Harari Group contains Harari and Eastern Guarage languages. Eastern Guarage is further subdivided into three branches, silt'e, wolane and zay languages. The language is spoken in Affar region, at Met'ek'leya, AbuleArada, and in Awash Fentale Woreda (Hussein, 2006:423), at Gachinne and its vicinity (Girma, 2003 E.C:10). It is also spoken in Amhara region at Dewwa Ch'effa Woreda of Oromiya zone at Shonke and T'allaha; and in North Shewa zone, in Ankober Woreda at AliyyuAmba and Afre; in K'ewot Woreda at Goze and Wank'ar; in Berehet Woreda at Mett'ehBila. According to Hussein (2006:434) mentions two dialects: the Shonke dialect which is spoken in Oromiya Special zone of Amhara region; and the Gachinne dialect which is spoken in Gachinne of Affar region, as well as in Ankober and Aliyyu Amba, North Shewa, Amhara region.

\section{Research Methodology}

The study is qualitative in nature, and mainly relies on primary linguistic data. Since the researcher is not a speaker of Argobba, native speakers of the language were consulted. The data were gathered from five native speakers of Argobba during 6 months of fieldwork conducted between 2015 and 2016 in Argobba Special woreda, South Wollo Zone of the Amhara Regional State, specifically in, Medina (Administrative center of the woreda) and five Kebeles which are nearest to Medina namely: Dibbe, Gobera, Kilkilo, Fetekuma, and Sedeta. During my fieldwork, I had three male and two female language consultants whose first native language was Argobba and who had a good knowledge of Amharic. They all were born within the speech community of Argobba where they also obtained their primary and secondary school education. Besides their native language and Amharic, they speak English. During my fieldwork, I spent most of my time in Medina which is the administrative center of the ArgobbaWoreda, but I also undertook several shorter trips to Dibbe, Gobera, Kilkilo, Fetekuma, and Sedeta. I started my fieldwork by eliciting 
words and sentences. Next, I recorded free speech texts then data were transcribed, edited and translated. The presentation of the data is not based on a single linguistic model or theory, but is intentionally eclectic descriptive. I used a structural approach for identifying phonemes and morphemes. Morpho-syntactic phenomena were described on the basis of major findings in linguistics typology. Based on The Leipzig Glossing Rules, most of the data are presented in an interlinear morpheme-by-morpheme version with four lines. The first line represents the actual utterance. The second line contains underlying or hypothetical morphemes or morpheme combinations which are glossed in the third line; the fourth line is an English translation usually in a literary style. Regarding assumptions and limitation of the study. The paper is descriptive in natureonly in Argobba and the reading does not handle properties, types of Intensifier, reflexive and reciprocal pronouns constructions in different languages - this remains a task for further research.

\section{Intensifiers, Reflexive and Reciprocal Pronouns in Argobba}

According to König (2001:747), intensifiers are pronouns which semantically put special emphasis on an argument of the verbal action. Morpho-syntactically, intensifiers either representor modify a noun phrase.

Intensifiers in Argobbaare derived from the noun hïms 'soul', which has the meaning 'self' as intensifier, or its reduplicated form hïms-lä-hïms 'each other (lit. soul with soul or self with self)'. In certain constructions, the intensifiers can function as reflexive or reciprocal pronouns, but reflexivity and reciprocity is basically expressed by verb derivation.

\section{Reflexive PronounsinArgobba}

According to Bhat (2004:79), the term reflexive is used for denoting co-reference between two different noun phrases inactions that affect the subject and the object. In Argobba, reflexive pronouns are formed by combining hïms 'self' with the possessive suffixes.

\begin{tabular}{|c|c|c|}
\hline \multirow[t]{4}{*}{ (1) } & $1 \mathrm{SG}$ & hümsïyye \\
\hline & & hïms-yye \\
\hline & & self-POSS.1SG \\
\hline & & 'I myself' \\
\hline \multirow[t]{4}{*}{ (2) } & 2SG.M & hümsïx \\
\hline & & hïms-x \\
\hline & & self-POSS.2SG.M \\
\hline & & 'you yourself' \\
\hline \multirow[t]{4}{*}{ (3) } & 2SG.F & hümsïs̆ \\
\hline & & hïms-š \\
\hline & & self-POSS.2SG.F \\
\hline & & 'you yourself' \\
\hline \multirow[t]{4}{*}{ (4) } & 3SG.M & hïmsu \\
\hline & & hïms-u \\
\hline & & self-POSS.3SG.M \\
\hline & & 'he himself' \\
\hline \multirow[t]{4}{*}{ (5) } & 3SG.F & hïmsa \\
\hline & & hïms-a \\
\hline & & self-POSS.3SG.F \\
\hline & & 'she herself' \\
\hline \multirow[t]{4}{*}{ (6) } & 1PL & hümsïno \\
\hline & & hïms-no \\
\hline & & self-POSS.1PL \\
\hline & & 'we ourselves' \\
\hline
\end{tabular}


(7)

2PL hïmsïxum

hïms-xum

self-POSS.2PL.M

'you yourselves'

(8) 3PL hïmsäm

hïms-äm

'you yourselves'

self-POSS.2PL.F

In (9) and (10), intensifier function as the reflexive pronouns occur in the direct and indirect object position, and their co-referentiality with the respective subjects is marked by possessive suffixes, which is commonly expected in reflexive constructions:

(9)

$\begin{array}{ll}\text { hïmsïnugädd'älä. } & \\ \text { hïms-n-u } & \text { gädd'äl-ä } \\ \text { self-ACC } & \text { kill.PFV-3SG.M } \\ \text { POSS.3SG.M } & \end{array}$

'He killed himself.'

(10) hïmsïnagädd'äläčč.

hïms-n-a gädd'äl-äčč

self-ACC kill.PFV-3SG.F

POSS.3SG.F

'She killed herself.'

(11) hümüsnüyyeišemmätäxuyharat ’̈ruy

hïms-n-yye i-šemmät-äxu-äy

self-ACC-POSS. REL-buy.PFV-1SG.SBJ-3S

1SG G.M.OBJ

Harat'ïru-äy

Sheep good-COP-3SG.M

'The sheep I bought for myself is nice.'

(12) hümsïnuišemmätäňňharat'ïruy

hïms-n-u i-šemmät-ä-äňn̆

self-ACC-POSS. REL-buy.PFV-3SG.SBJ-3S

3SG.M G.M.OBJ

harat’ïru-äy

Sheep good-COP-3SG.M

'The sheep he bought for himself is nice.'

However, the reflexive pronouns are also frequently used to emphasize acting as an agent of the subject, as in (13), i.e. here they function as intensifiers: 


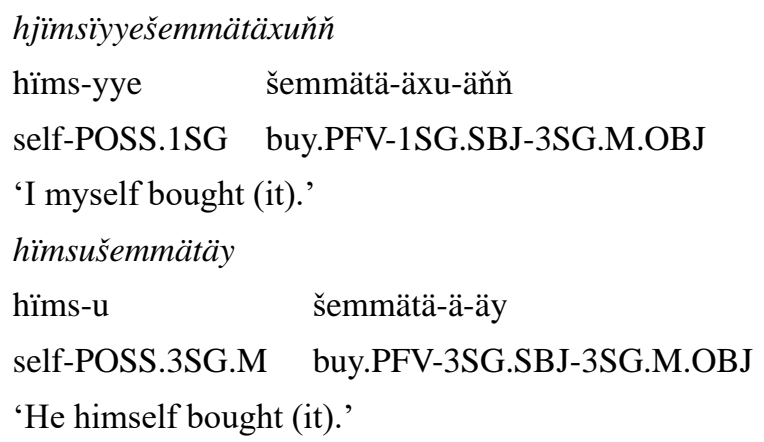

\section{Reciprocal Pronounsin Argobba}

According to Bhat (2004:85), reciprocity is primarily concerned with the predicate. It resembles reflexive meaning in some respects, but differs from it in others. The most important difference between the two is that the notion of 'co-reference' is a real one in the case of reflexive meaning, while in the case of reciprocal meaning; it is illusory subject and object act against each other.

In Argobba, there are two types of reciprocal pronouns. First, reciprocal pronouns can be formed through a construction consisting of the comitative morpheme tä-, which intersects between the reduplicated noun hïms 'self', and the plural possessive suffixes.

1PL hïmsïtähümïno

$\begin{array}{ll}\text { hïms-tä-hïms } & \text {-no } \\ \text { self-COM-self } & \text {-POSS.1PL }\end{array}$

$\begin{array}{lll} & \text { hïms-tä-hïms } & \text {-xum } \\ \text { self-COM-self } & \text {-POSS.2PL } \\ \text { 'you - each other' } & \\ \text { 3PL } & \text { hïmsïtähümïsäm } & \\ & \text { hïms-tä-hïms } & \text {-äm } \\ \text { self-COM-self } & \text {-POSS.3PL } \\ \text { 'they - each other' } & \end{array}$

The other type of reciprocal pronouns is formed through the reduplicated plural personal pronouns which are connected by the comitative marker tä -:

\begin{tabular}{|c|c|c|}
\hline (18) & 1PL & ïnnatïnna \\
\hline & & ïnna-tä-ïnna \\
\hline & & 1PL-COM-1PL \\
\hline & & 'we - each other' \\
\hline (19) & $2 \mathrm{PL}$ & ankumtankum \\
\hline & & ankum-tä-ankum \\
\hline & & 2PL.M-COM-2PL.M \\
\hline & & 'you - each other' \\
\hline (20) & $3 P L$ & illlämtälläm \\
\hline & & ïlläm-tä-ïlläm \\
\hline & & 3PL.M-COM-3PL.M \\
\hline & & 'they - each other' \\
\hline
\end{tabular}


The reciprocal pronouns emphasize the concept of reciprocity, which is basically encoded through a verb derivation. Therefore, the use of the reciprocal pronouns in sentences like (21) is optional, i.e. these pronouns mainly function as intensifiers:

$$
\begin{aligned}
& \text { illämtällämtät'rarräy. } \\
& \text { iilläm - tä-ïlläm tät'ïrarr-äy } \\
& \text { 3PL.M COM-3PL.M [call_each_other.PFV-3PL.M] }]_{\mathrm{RE}} \\
& \mathrm{CP} \\
& \text { 'They call each other.' } \\
& \text { (22) ankumtankumtägïdaddäläy. } \\
& \text { ankumm - tä-ankum tägïdaddäl-äy } \\
& \text { 2PL.M COM-2PL. [call_each_other.PFV-2PL.M] }]_{\text {RE }} \\
& \mathrm{M} \quad \mathrm{CP}
\end{aligned}
$$

\section{Summary and Conclusion}

This chapter summarizes the findings from the previous section on the introduction and Intensifiers, reflexive and reciprocal pronounsof Argobba. Thus, the major aim of this study was to present a comprehensive Intensifier, reflexive and reciprocal pronouns of this language. To this effect the study is divided into two main sections: section one is introduction which contains the people and their language, and research methodology, section two is Intensifiers, reflexive and reciprocal pronouns in Argobba language that is spoken in Argobba special Woreda in south Wollo of the Amhara regional state, Ethiopia. The paper is descriptive in nature, since the study is mainly concerned with describing what is actually being in the language, and mainly relies on primary linguistic data. The linguistic data, i.e. the elicited grammatical data concerning Intensifiers, reflexive and reciprocal pronouns, was collected from native speakers of the language during 6 months of fieldwork.Intensifiers in Argobbaare derived from the noun 'soul', which has the meaning 'self' as intensifier, or its reduplicated form 'each other (lit. soul with soul, or self with self)'. In certain constructions, the intensifiers can function as reflexive or reciprocal pronouns, but reflexivity and reciprocity is basically expressed by verb derivation.Reflexive pronouns are formed by combining 'self' with the possessive suffixes.Intensifier function as the reflexive pronouns occur in the direct and indirect object position, and their co-referentiality with the respective subjects is marked by possessive suffixes, which is commonly expected in reflexive constructions. The reflexive pronouns are also frequently used to emphasize acting as an agent of the subject, i.e. here they function as intensifiers. The language has two types of reciprocal pronouns. One is that can be formed through a construction consisting of the comitative morpheme, which intersects between the reduplicated noun 'self', and the plural possessive suffixes and the other is formed through the reduplicated plural personal pronounswhich are connected by the comitative marker.The reciprocal pronouns emphasize the concept of reciprocity, which is basically encoded through a verb derivation that can be optional.

To conclude, this study provides a comprehensive description of the main Intensifier, reflexive and reciprocal pronouns of Argobba.

\section{List of Abbreviations and Symbols}

$\begin{array}{ll}1 & \text { first person } \\ 2 & \text { second person } \\ 3 & \text { third person } \\ \text { SG } & \text { singular } \\ \text { POSS } & \text { possessive } \\ \text { F } & \text { feminine } \\ \text { M } & \text { masculine } \\ \text { PL } & \text { plural } \\ \text { ACC } & \text { accusative } \\ \text { PFV } & \text { Perfective }\end{array}$




$\begin{array}{ll}\text { DAT } & \text { dative } \\ \text { REL } & \text { relative } \\ \text { SBJ } & \text { subject } \\ \text { OBJ } & \text { object } \\ \text { CAUS.D } & \text { direct causative } \\ \text { CNV } & \text { converb } \\ \text { IP } & \text { impersonal } \\ \text { IPFV } & \text { imperfective } \\ \text { M } & \text { masculine } \\ \text { COP } & \text { copula } \\ \text { COM } & \text { comitative } \\ \text { RECP } & \text { reciprocal } \\ \text { References } & \end{array}$

Ahmed, M. I. (1999 E.C). Civilization and History of Makzumit and Hashimite Wolasma Kingdoms in Ethiopia; Issues on the Origin and Identity of the Argobba People. Book One. Addis Ababa. (written in Amharic).

Aklilu, A. (2000). A Short History of the Argobba. In: Annales D'Ethiopie, Vol. XVI, annee 2000. 173-183. https://doi.org/10.3406/ethio.2000.973

Bhatt, R. (2004). Conditionals. In: The Blackwell Companion to Syntax, eds. Martin Bert Hans Everaert \& Hendrik Cornelis van.

Central Statistical Agency. (2008). The 2008 National Statistics [of Ethiopia]. Retrieved from www.csa.gov.et on 22 August 2016.

Girma, A. (2003). Argobba-Amharic Dictionary. Jebert Vol. 3. (written in Amharic).

Hetzron, R. (1972). Ethiopian Semitic Studies in Classification. Manchester: Manchester University Press.

Hetzron, R., \& Marvin, L. B. (1976). TheEthio-Semitic Languages. In: Marvin L. Bender, James D. Bowen, Robert L. Cooper and Charles A. Ferguson (eds.), Language in Ethiopia. London: Oxford University Press, 77-90.

Hussein M. (2006). Sociolinguistic Survey among ethnically Argobbacommunities. In Ethiopian Languages Research Center, Vol. II (number 4).415-454.

Idris, M. (1999). Ethiopia and Islam. (translated from Arabic to Amharic (Arabic author Mohammed bin Yusuf).

König, E. (2001). Intensifiers and Reflexive Pronouns. In: Martin Haspelmath, EkkehardKönig, WulfOesterreicher and Wolfgang Raible (eds.), Language Typology and Language Universals. An International Handbook. Volume 1. Berlin and New York: Walter de Gruyter, 747-760.

Meyer, R. (2011). Gurage. In: Stefan Weninger (ed.), The Semitic Languages: An International Handbook. Berlin and New York: De Gruyter Mouton, 1220-1257. https://doi.org/10.1515/9783110251586.1220

Stitz, V. (1973). The Western Argobba of Yifat, Centraal Ethiopia. In: Proceedings of the First United States Conference on Ethiopian Studies. Michigan: Michigan State University, African Studies Center. 2-5 May/1973.185-192.

Tesfaye, H. (2000). History and Culture of the Argobba: RecentInvestigations. In: Annales d'Ethiopie, XVI, $195-206$. https://doi.org/10.3406/ethio.2000.975

Weekes, R. V. (1984). Muslim Peoples.A World Ethnographic Survey.2nd ed. Greenwood Press. 